OPEN ACCESS

Edited by:

Mingbo Yin,

Fudan University, China

Reviewed by:

Silvio Erler,

Julius Kühn-Institut, Germany

Eugene Ryabov,

United States Department of Agriculture (USDA), United States

*Correspondence:

Matti Leponiem

matti.leponiemi@edu.uni-graz.at

Specialty section:

This article was submitted to Behavioral and Evolutionary Ecology,

a section of the journal

Frontiers in Ecology and Evolution

Received: 06 November 2020

Accepted: 08 February 2021

Published: 02 March 2021

Citation:

Leponiemi M, Amdam GV and

Freitak D (2021) Exposure

to Inactivated Deformed Wing Virus

Leads to Trans-Generational Costs

but Not Immune Priming

in Honeybees (Apis mellifera).

Front. Ecol. Evol. 9:626670.

doi: 10.3389/fevo.2021.626670

\section{Exposure to Inactivated Deformed Wing Virus Leads to Trans-Generational Costs but Not Immune Priming in Honeybees (Apis mellifera)}

\author{
Matti Leponiemi' ${ }^{1 *}$,Gro V. Amdam ${ }^{2,3}$ and Dalial Freitak ${ }^{1}$ \\ ${ }^{1}$ Institute of Biology, University of Graz, Graz, Austria, ${ }^{2}$ Faculty of Environmental Sciences and Natural Resource \\ Management, Norwegian University of Life Sciences, Ås, Norway, ${ }^{3}$ School of Life Sciences, Arizona State University, Tempe, \\ $A Z$, United States
}

Pathogens are identified as one of the major drivers behind the honeybee colony losses, as well as one of the reasons for the reported declines in terrestrial insect abundances in recent decades. To fight infections, animals rely on their immune system. The immune system of many invertebrates can be primed by exposure to a pathogen, so that upon further exposure the animal is better protected. The protective priming effect can even extend to the next generation, but the species capable of priming the immune system of their offspring are still being investigated. Here we studied whether honeybees could prime their offspring against a viral pathogen, by challenging honeybee queens orally with an inactivated deformed wing virus (DWV), one of the most devastating honeybee viruses. The offspring were then infected by viral injection. The effects of immune priming were assayed by measuring viral loads and two typical symptoms of the virus, pupal mortality, and abnormal wing phenotype. We saw a low amount of wing deformities and low pupal mortality. While no clear priming effect against the virus was seen, we found that the maternal immune challenge, when combined with the stress caused by an injection during development, manifested in costs in the offspring, leading to an increased number of deformed wings.

Keywords: immune priming, DWV, Apis mellifera, trans-generational, costs

\section{INTRODUCTION}

In their natural environment animals may encounter variety of stressors at any time. Among others, pathogens, parasites, and toxic substances have often significant negative fitness consequences, like reduced fecundity or survival (Kammenga et al., 1997; Fitze et al., 2004), especially when encountered simultaneously (Sih et al., 2004). Organisms can fight stressors by avoidance, physical barriers, or by physiological responses, for example by producing enzymes that break down harmful toxins (Feyereisen, 1999). The physiological resistance mechanism against pathogens is the immune system (Siva-Jothy et al., 2005). In vertebrates, adaptive immunity relies on production of antibodies, proteins that can recognize and quickly respond to the same pathogen later, providing long lasting protection (Farber et al., 2016). Despite lacking the immune machinery for producing 
antibodies, insects, and other invertebrates are still able to prime their immune system and have increased protection against pathogens they have encountered before. An initial exposure to a pathogen primes the organisms innate immune system to provide increased protection upon secondary exposure, although the protection may vary in length and specificity (Milutinović and Kurtz, 2016). Immune priming has been observed in variety of invertebrate taxa, most notably in insect hosts, such as the Indian-meal moth (Tidbury et al., 2011), the red flour beetle (Roth et al., 2009), and the bumble bee (Sadd and SchmidHempel, 2006). The priming effects have been shown to extend to the next generation (Tetreau et al., 2019), providing offspring protection against pathogens that are expected to be found in the environment (Pigeault et al., 2016).

Understanding the interaction between stressors and resistance mechanisms is increasingly important, as more species are at risk of extinction (Bongaarts, 2019). In recent decades, alarming declines in insect populations have been observed (Forister et al., 2011; Hallmann et al., 2017). A new meta-analysis of available long term surveys from around the world estimated an $8.81 \%$ decline per decade in terrestrial insect abundance (Klink et al., 2020). The major drivers for this decline include habitat loss, climate change, stressors like synthetic pesticides and fertilizers, and pathogens (Sánchez-Bayo and Wyckhuys, 2019). Pathogens can seriously affect natural populations (Skerratt et al., 2007), but managed populations are suffering from disease outbreaks as well. Managed honeybees have also faced similar problems with bacterial and viral pathogens causing high colony mortality, especially when combined with other stressors like pesticides (Smith et al., 2013; Grassl et al., 2018), parasites (Nazzi et al., 2012), or poor nutrition (Belzunces et al., 2013). The increased mortality of honeybee colonies has received a lot of attention, as they are important pollinators of many crops (Klein et al., 2007). The diseases in managed honeybee colonies pose a risk to wild populations too, as viruses can spread between managed bees and wild bees when foraging in the same area (Fürst et al., 2014; Mazzei et al., 2014; Alger et al., 2019). One of the most devastating pathogens associated with the colony losses is the deformed wing virus (DWV), an RNA virus in the family Iflaviridae (de Miranda and Genersch, 2010). Stated symptoms of the DWV include bloated abdomen, discoloration, mortality at the pupal stage, and abnormally developed wings (de Miranda and Genersch, 2010). DWV is transmitted by the ectoparasitic mite Varroa destructor, which has spread all around the world, causing the ongoing pandemic among honeybees (Nazzi and Le Conte, 2016). Bees may get infected as adults by phoretic mites, or at the pupal stage in the enclosed brood cell. When in the brood cell, the mite feeds on the hemolymph and fat body of the developing bee, simultaneously infecting it with the virus (Ramsey et al., 2019).

A major antiviral defense mechanism in insects and many other organisms is the RNAi-system (Lemaitre and Hoffmann, 2007). Bees have a lower number of immune related genes when compared to most insects, but the same major pathways are functional, including the RNAi (Evans et al., 2006; Barribeau et al., 2015). The RNAi-system indeed seems to be involved in the honeybee antiviral defense (Brutscher and Flenniken, 2015).
Studies done with DWV and Israeli Acute Paralysis Virus have shown that activating the RNAi-system by feeding virus-specific dsRNA to larvae or adult bees before an infection reduces the viral load, mortality and symptoms resulting from the specific viral infection (Hunter et al., 2010; Desai et al., 2012). The transfer of virus specific dsRNA or other virus derived immune elicitors to the next generation could therefore be a mechanism for transgenerational immune priming (TGIP). The mechanism for such maternal transfer of immune elicitors to the next generation has been discovered in honeybees (Salmela et al., 2015). After an immune challenge from bacteria, fragments of the bacteria bind to the multifunctional protein vitellogenin which is then transferred to the eggs and thus to the next generation (Salmela et al., 2015). Indeed, challenging the queen with a bacterial pathogen, Paenibacillus larvae, which is exclusively infecting only the young brood, increased resistance to this pathogen in the infected offspring (Hernández López et al., 2014). Transgenerational protection against viruses has been found in the nematode Caenorhabditis elegans (Rechavi et al., 2011) and in the Indian-meal moth Plodia interpunctella (Tidbury et al., 2011). Although observed in other hosts, the occurrence of antiviral TGIP in honeybees is unclear.

We used the honeybee-DWV system to investigate TGIP against viral pathogens. We hypothesized that a challenge of the honeybee queen with inactivated virus could lead to increased resistance against the virus in the offspring. We used heat inactivated DWV to orally challenge honeybee queens and infected the brood by DWV injection at the pupal stage. TGIP has been observed before with heat killed bacteria (Sadd et al., 2005; Hernández López et al., 2014), so we decided to use heat inactivated DWV to avoid exposing colonies to live pathogens which could spread to the environment. Injection resembles the natural infection route, as feeding mites also pierce the cuticle and viruses enter the hemolymph via saliva. Pupal mortality was measured following the infection. When the offspring emerged as adults, we measured the proportions of bees with wing deformities and viral loads with quantitative polymerase chain reaction (qPCR). In case the honeybee queen would be able to increase the resistance of their offspring against the DWV by TGIP, we would expect to see reduced symptoms or lower viral loads in the infected offspring.

\section{MATERIALS AND METHODS}

\section{Honeybees and Virus}

The honeybee (Apis mellifera) colonies used in this experiment were located in the Arizona State University Bee Lab in Mesa, AZ, United States. All colonies were healthy and had been subjected to $65 \%$ formic acid treatment to control Varroa. All queens were bred in the Bee lab and mated using open mating approach. After mating the queens were allowed to begin laying eggs in nucleus colony hive. Only sister queens were used for the study. DWV, clone-derived strain pDWV-USDA-703 of genotype DWV-A (Ryabov et al., 2019) was obtained as a ready suspension with concentration of $10^{\wedge} 7$ transcripts per $\mu l$ from USDA Agricultural Research Center in Beltsville, MD, United States. 


\section{Queen Treatments}

Twenty-four honeybee queens were divided into two treatment groups - a priming treatment and control treatment, 12 individuals in each. In the priming treatment the queens were orally immune challenged with inactivated DWV in feed (see below for details on feed preparation). Control queens were fed with Phosphate-buffered saline (PBS) in feed. After the queens were removed from their respective hives for the priming treatment, all the hives were treated with a queen mimicking pheromone to simulate the presence of the queen. Removed queens were placed in individual queen cages with the treatment queen feed and seven accompanying worker bees. The queen cages were kept in an incubator at $34^{\circ} \mathrm{C}$ on top of moistened sponges for 7 days. The queens were then returned to their respective hives in the queen cages, allowing the worker bees to free the queens via feeding though the remaining feed. To ensure that the brood used in the experiment was laid after the queens returned to the hives, a fresh frame was provided for egg laying.

Two queens died during the priming treatment (one from each treatment). The final number of queens returned to the hives was thus 11 per treatment, resulting in 22 queens in total.

\section{Preparation of Queen Feed}

The feed for queen treatments was prepared with inactivated virus suspended in a commercial bee feed containing $85.5 \%$ sugar (Ambrosia feed paste - Nordzucker, Germany). In total, 24 bee feed patties were prepared: 12 containing inactivated virus and 12 control patties. To inactivate the virus, the virus suspension was kept at $95^{\circ} \mathrm{C}$ for $60 \mathrm{~min}$ (MJ Research PTC-200 Peltier Thermal Cycler) (Carrillo-Tripp et al., 2016). Ninety-six microliters of inactivated DWV suspension and $454 \mu \mathrm{l}$ of $1 \mathrm{x}$ PBS were mixed to obtain $550 \mu \mathrm{l}$ of the DWV priming suspension. To prepare priming patties, $44 \mathrm{~g}$ of bee feed was quickly melted in a glass container in a microwave and mixed with $550 \mu \mathrm{l}$ of the DWV priming suspension, resulting in $8 \times 10^{\wedge} 7$ virus transcripts per patty. For control treatment patties, $550 \mu \mathrm{l}$ of $1 \mathrm{x}$ PBS was mixed into the melted bee feed. The mixtures were poured into a thin aluminum foil vessel and let to solidify at $4^{\circ} \mathrm{C}$.

\section{Pupal Injection-Treatments}

Following the queen treatments, when the newly laid brood reached the white-eyed pupal stage, 30 white-eyed pupae from each hive were extracted from the cells using forceps in the laboratory. After extraction, the pupae were subjected to one of three treatments, 10 pupae in each. As there were 11 hives in each queen treatment, and 10 pupae from each hive were subjected to one of the three pupal treatments, the number of pupae in the six different queen-pupae treatment combinations was 110 . Two hives had only 28 right age pupae, and one hive had 29, making the total in these treatments 108 and 109, respectively (total $n=655$ ). The pupae were injected either with $1 \mu \mathrm{l} 1 \mathrm{x}$ PBS in the control treatment, $1 \mu \mathrm{l}$ live $10^{\wedge} 7 \mathrm{DWV}$ suspension in the infection treatment or left untreated in the naive treatment. The white-eyed stage is the stage at which the bees are naturally infected with the Varroa-mite (Donze and Guerin, 1994). One microliter of $10^{\wedge} 7 \mathrm{DWV}$ transcripts was chosen as the infection concentration, as a pre-experiment suggested that this concentration resulted in roughly equal amounts of good and deformed wings. Injections were performed using a $10 \mu \mathrm{l}$ Hamilton syringe with a $30 \mathrm{G}$ needle (BD). The needle was inserted at a low angle between the fourth and fifth tergite in the lateral abdomen, close to the site on the body where the mite feeds (Rosenkranz et al., 2009; Boncristiani et al., 2013; Ramsey et al., 2019).

After the injections, the pupae were placed on a folded filter paper (Supplementary Figure 1) on a Petri dish and checked daily until emergence. The Petri dishes were kept on a water bath in a closed plastic container to ensure relative humidity over $50 \%$ (Williams et al., 2013). The plastic container was placed in an incubator at $34^{\circ} \mathrm{C}$ until the pupae emerged as adults.

\section{Bioassays}

\section{Survival}

Following the pupal injection treatments, survival of the pupae ( $n=655)$ was monitored daily. After 10 days all individuals had either emerged as adult bees or died. Dead individuals were removed during monitoring.

\section{Wing Phenotype}

The wing phenotype was documented for each emerged adult bee $(n=617)$ at the day of emergence by visual observation. The wings were classified as being deformed or normal (Supplementary Figure 2).

\section{Viral Load Quantification}

A subset of three emerged adult bees of the ten pupae receiving injection treatment from each hive were used for the viral load assay (total $n=185$ ). We chose to use only fat body as the sample to measure viral concentrations. DWV has been previously shown to be present in the abdomen of all infected bees in high numbers and specifically in the fat body (Yue and Genersch, 2005; Fievet et al., 2006), while contaminants from the eyes may inhibit PCR reactions (Evans et al., 2013). Viral loads were quantified by real-time quantitative $\mathrm{PCR}$, and virus replication numbers were normalized to the reference gene actin.

\section{RNA extraction}

The worker bees were dissected, the fat body was placed in a $1.5 \mathrm{ml}$ microcentrifuge tube and homogenized with a pestle in $300 \mu \mathrm{l}$ of Trizol. Samples were stored overnight at $-80^{\circ} \mathrm{C}$, homogenized further, $700 \mu \mathrm{l}$ of Trizol and $200 \mu \mathrm{l}$ of chloroform per sample was added, mixed vigorously, and centrifuged at $12,000 \mathrm{~g}$ for $20 \mathrm{~min}$ at $4^{\circ} \mathrm{C}$. The upper aqueous phase containing the RNA was then transferred to new tubes with $500 \mu \mathrm{l}$ isopropyl alcohol and incubated in $-80^{\circ} \mathrm{C}$ for $1 \mathrm{~h}$. The samples were centrifuged again at $12,000 \mathrm{~g}$ for $30 \mathrm{~min}$ at $4^{\circ} \mathrm{C}$. Supernatant was removed, and $1 \mathrm{ml}$ of $75 \%$ ethanol was added to wash the RNA pellet. After a quick centrifugation, all supernatant was removed, and the samples were air dried for $10 \mathrm{~min}$. The RNA pellet was then dissolved in $50 \mu \mathrm{l}$ of nuclease free water and stored at $-80^{\circ} \mathrm{C}$ until further analysis. To eliminate any genomic DNA contamination, all the RNA samples were treated with DNase, using DNase I, RNase-free kit (Thermo Fisher Scientific, United States) 
according to manufacturer's instructions. RNA concentration was measured with NanoDrop 2000 Spectrophotometer (Thermo Fisher Scientific, United States).

\section{$q P C R$}

Qiagen QuantiTect SYBR Green RT-PCR kit with $12.5 \mu \mathrm{l}$ final reaction volume was used for the reverse transcription and qPCR reactions on a 384-well plate, with primers shown in Supplementary Table 1. The plates were ran on Bio-Rad C1000 Thermal Cycler CFX384 Real-Time System with an initial reverse transcription phase for $30 \mathrm{~min}$ at $50^{\circ} \mathrm{C}$, an initial PCR activation step for $15 \mathrm{~min}$ at $95^{\circ} \mathrm{C}$, followed by 40 cycles with $15 \mathrm{~s}$ of denaturation step at $94^{\circ} \mathrm{C}, 31 \mathrm{~s}$ annealing step at $52^{\circ} \mathrm{C}$ and $30 \mathrm{~s}$ extension and data collection step at $72^{\circ} \mathrm{C}$.

\section{Statistical Methods}

All analyses were done with $\mathrm{R}$ version 3.4.1 (R Core Team, 2017). For statistical analyses packages lme4 (Bates et al., 2015), survival (Therneau, 2015), multcomp (Hothorn et al., 2008), and nlme (Pinheiro et al., 2021) were used, and for figures survminer (Kassambara and Kosinski, 2017).

Pupal survival was analyzed with survival regression analysis. Queen treatment and pupal treatment were included as fixed effects, as well as interaction. Hive was treated as a random effect in the model.

Interactions between the treatment groups for wing phenotypes were compared with a generalized linear mixed model (Bolker et al., 2009), with binomial distribution and probit link function. Wing phenotype was the response variable, queen and pupal treatments were included as fixed effects, with interaction, and hive as a random effect.

Viral loads between groups were analyzed by calculating the $\Delta \mathrm{Ct}$ according to the 2- $\Delta \Delta \mathrm{Ct}$-method (Livak and Schmittgen, 2001). We used primers that have been used in several studies, with reported efficiencies close to 2 (Supplementary Table 1). Viral loads were analyzed with a weighted linear mixed model, log-transformed $2^{\wedge}-\Delta \mathrm{Ct}$-value being the response variable and queen and pupal treatments were the interacting fixed effects, with hive as a random effect. The individuals from one control queen plus three other individuals were excluded from this analysis because there was not enough RNA in the samples, and one outlier was removed. Calculated dCt values are available in Supplementary Table 2.

\section{RESULTS}

\section{Pupal Survival}

After the pupal treatments, the mortality of the pupae was documented. Mortality was below $11 \%$ in all groups, even in the ones infected with virus (Figure 1). Pupal mortality was not affected by the queen priming treatments or injection of the virus, as there were no significant effects in the survival model (Table 1).

\section{Wing Phenotype}

We observed the wing phenotype of each emerged adult bee and found deformed wings in all treatment groups, also in the

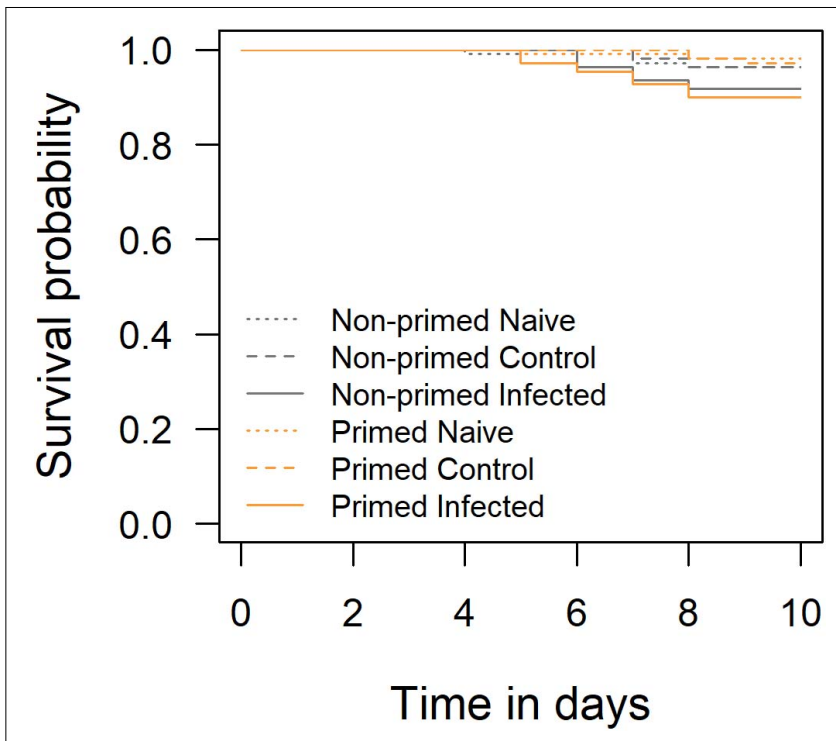

FIGURE 1 | Survival probabilities of pupae after pupal injection treatments. Orange lines showing pupae from primed queens, gray lines from non-primed control queens.

TABLE 1 | Results from survival regression model.

\begin{tabular}{lcccc}
\hline Parameter & Estimate & SE & $\boldsymbol{z}$ & $\boldsymbol{P}$-value \\
\hline Intercept & $\mathbf{3 . 5 0 3}$ & $\mathbf{0 . 2 8 8}$ & $\mathbf{1 2 . 1 4}$ & $\mathbf{< 0 . 0 0 0 1}$ \\
Queen primed & 0.283 & 0.302 & 0.94 & 0.35 \\
Pupae control & 0.005 & 0.242 & 0.02 & 0.98 \\
Pupae infected & -0.294 & 0.210 & -1.40 & 0.16 \\
Queen primed $\times$ Pupae control & -0.142 & 0.395 & -0.36 & 0.72 \\
Queen primed $\times$ Pupae infected & -0.315 & 0.337 & -0.93 & 0.35
\end{tabular}

Bold was used to highlight significant values ( $p<0.05)$.

ones not infected with the virus (Figure 2). The percentage of normally developed wings in the infected pupae from primed and non-primed queens were $62 \%$ and $60 \%$, while in the naïve group they were $72 \%$ and $70 \%$, respectively. In the PBSinjected group $74 \%$ of the offspring of non-primed queens had normally developed wings, but only $58 \%$ of the offspring of primed queens. The interaction of queen treatment and PSBinjection treatment thus caused an increase in the number of wing deformities (Figure 2 and Table 2). Otherwise no significant effects were found.

\section{Viral Load}

To measure viral load the relative loads were quantified by real time quantitative PCR. The highest relative viral loads were observed in the infected pupae of primed and non-primed queens (Figure 3 and Table 3). Naïve and control pupae had lower but detectable viral loads, even though not infected in the experiment. The lowest viral loads were found in the naïve offspring of non-primed queens, while the PBS-injected offspring from non-primed queens had slightly higher viral load. The PBS-injected offspring of primed queens had load 


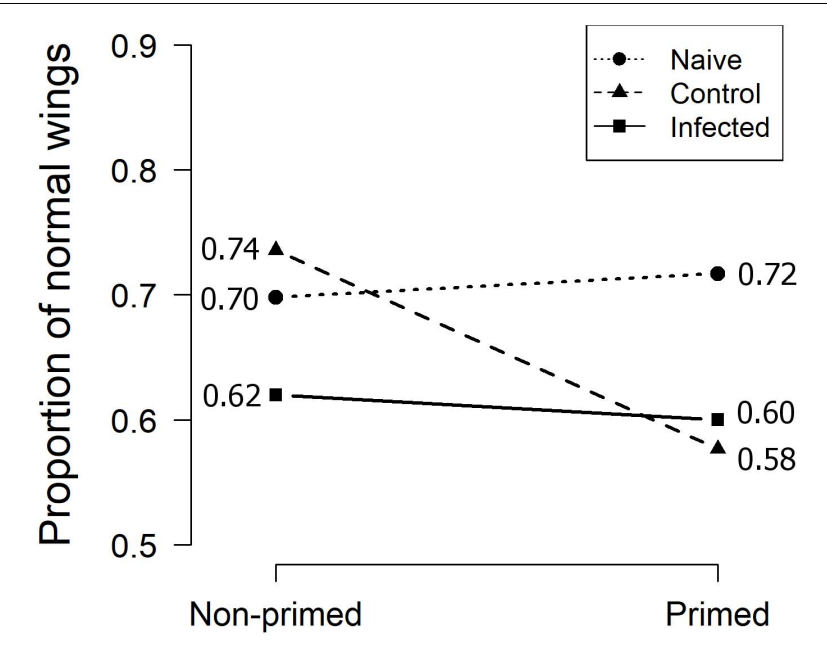

Queen treatment

FIGURE 2 | Proportions of normally developed wings among emerged adult bees of non-primed and primed queens. $Y$-axis from 0.5 to 0.9 .

TABLE 2 | Results from the generalized linear mixed model on wing phenotype.

\begin{tabular}{lcccc}
\hline Parameter & Estimate & SE & $\boldsymbol{Z}$ & $\boldsymbol{P}$-value \\
\hline Intercept & $\mathbf{0 . 5 2 5}$ & $\mathbf{0 . 1 5 3}$ & $\mathbf{3 . 4 1 6}$ & $\mathbf{0 . 0 0 0 6}$ \\
Queen primed & 0.076 & 0.219 & 0.346 & 0.729 \\
Pupae control & 0.131 & 0.186 & 0.706 & 0.480 \\
Pupae infected & -0.222 & 0.184 & -1.209 & 0.227 \\
Queen primed x Pupae control & $-\mathbf{0 . 5 3 7}$ & $\mathbf{0 . 2 6 2}$ & $-\mathbf{2 . 0 5 5}$ & $\mathbf{0 . 0 3 9}$ \\
Queen primed x Pupae infected & -0.120 & 0.262 & -0.456 & 0.648 \\
\hline
\end{tabular}

Bold was used to highlight significant values $(p<0.05)$.

similar to the naïve baseline. All the terms in the model were significant (Table 3 ).

\section{DISCUSSION}

In this study we see pronounced effect of maternal stressors on the wing deformation of the offspring and complex effects on the offspring viral load. At the same time, no clear priming effect of challenging the queens with heat inactivated DWV was evident in the offspring. The pupal mortality was low in both infected groups, and no differences in mortality was found between the infected and control pupae. This is consistent with other studies (Möckel et al., 2011; Remnant et al., 2019; Tehel et al., 2019), showing that DWV infection alone might not result in high pupal mortality.

The PBS-injected offspring of primed queens had significantly more deformed wings than the offspring of non-primed queens, indicating a trans-generational cost from the maternal immune challenge. We do not see as many deformed wings in the primed naive offspring, indicating that the cost of the queen immune challenge is only evident in the offspring when they were also exposed to another stressor, the injection treatment. The injection causes wounding, which may cause unspecific immune

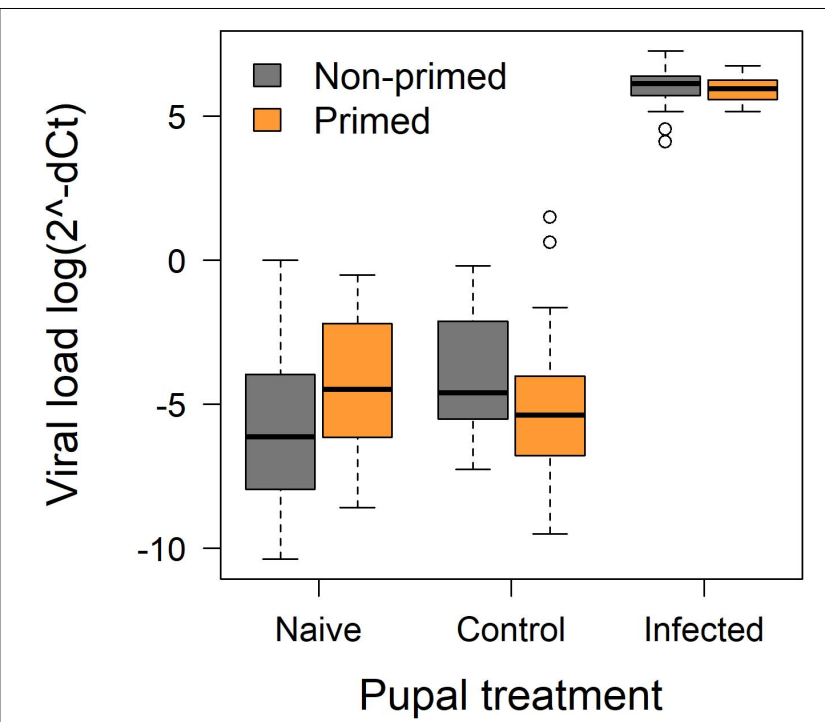

FIGURE 3 | Median and quartiles of the $\log (2 \hat{-}-\Delta \mathrm{Ct})$-values for each treatment group with outliers. Orange boxes represent offspring from primed queens, gray from non-primed control queens.

TABLE 3 | Results from the weighted linear mixed model on viral loads.

\begin{tabular}{lcccc}
\hline Parameter & Estimate & SE & $t$ & $P$-value \\
\hline Intercept & -5.775 & 0.477 & -12.117 & $<0.001$ \\
Queen primed & 1.408 & 0.629 & 2.238 & 0.037 \\
Pupae control & 1.722 & 0.599 & 2.876 & 0.005 \\
Pupae infected & 11.811 & 0.477 & 24.761 & $<0.001$ \\
Queen & -2.803 & 0.863 & -3.246 & 0.001 \\
primed x Pupae & & & & \\
control & & & & \\
Queen & -1.515 & 0.627 & -2.419 & 0.017 \\
primed x Pupae & & & & \\
infected & & & &
\end{tabular}

Bold was used to highlight significant values ( $p<0.05)$.

system activation and additional costs (Erler et al., 2011). It is possible that all offspring of primed queens suffered costs in other aspects that were not investigated in this experiment. Some wing deformities in all treatments were probably caused by handling stress, as artificial rearing conditions in the lab are suboptimal for bee development. Our results showing costs from maternal immune challenge are generally consistent with previous TGIP studies showing developmental costs for the offspring. We know that maternal immune challenges can cause tradeoffs in the offspring, like prolonged developmental time that were observed in the beetles Tenebrio molitor and Tribolium castaneum (Zanchi et al., 2011; Schulz et al., 2019). In the moth Manduca sexta the individuals developed faster, but had reduced fecundity (Trauer and Hilker, 2013). Costs from maternal immune challenge for offspring may also manifest in other ways, as was shown in bumble bees, when maternal immune challenge reduced offspring resistance to unrelated pathogens (Sadd and Schmid-Hempel, 2009). 
Previously wing deformities have been associated with the horizontal transmission by Varroa mite feeding, as similar injection experiments have resulted in wing deformities in a dose dependent manner (Möckel et al., 2011). Also, the DWV genotype $\mathrm{A}$ has been claimed less virulent than genotype $\mathrm{B}$ (McMahon et al., 2016). In this study using DWV genotype A, we observed both low mortality as well as low amount of wing deformities, when compared to other studies (Tehel et al., 2019; Dubois et al., 2020). We saw deformed wings in only $38 \%$ of the primed and $40 \%$ of the non-primed infected bees, while in the non-primed control group $24 \%$ had deformed wings. In other studies with similar methodology, a substantially lower inoculation concentration lead to $60-74 \%$ of bees developing deformed wings, while the number in control groups were similar to ours (Tehel et al., 2019; Dubois et al., 2020). However, these studies used inocula extracted from naturally infected bees, whereas an inoculum prepared from honeybee pupae infected with a cDNA clone was used in our study (Ryabov et al., 2019). Our results indicate that even after infected with a high concentration of DWV $\left(10^{\wedge} 7 / \mu \mathrm{l}\right)$, pupal mortality and amount of wing deformities may still be low relative to control, probably because of low virulence of the particular strain.

We found high but similar viral loads in the infected groups, regardless of the maternal priming treatment. The lowest viral load was found in the naïve offspring of non-primed queens. DWV is often found even in asymptomatic hives as a covert infection (Martin and Brettell, 2019), and in our case the virus is indeed detectable as a background baseline infection in the bees that were not injected with the virus. Interestingly, we found higher viral titers in naïve individuals from primed queens. This could result from the transmission of viral templates from the queen priming treatment that were then detected by the realtime quantitative PCR, consistent with the transfer of pathogen particles as a mechanism for TGIP (Salmela et al., 2015). The PBSinjected offspring from non-primed queens had slightly higher viral load, showing that the injection of PBS alone could lead to the higher titers of a latent background infection, as has been shown before (Anderson and Gibbs, 1988). In contrast, the PBS-injected offspring of primed queens had comparably lower viral load, similar to the naïve baseline. We hypothesize, that the background infection is low enough to not induce an antiviral response (Moreno-García et al., 2014), but the additional challenges of injection and maternal immune challenge caused an increased immune response, activating also the antiviral pathways. This resulted in the observed lower viral titers in the primed control bees, but immune responses being costly (Moret and Schmid-Hempel, 2000), contributed to the increased wing deformities observed in this treatment group.

Although TGIP with viruses have been studied less, recently the existence of antiviral TGIP in fruit flies and mosquitoes was shown, lasting for multiple generations (Mondotte et al., 2020). The mechanism was found to be virus specific, RNAi independent and was shown with multiple positive strand RNAviruses, which the DWV also is. In mosquitoes the oral infection route was also effective, although live virus was used. The methods in our study are closely resembling the ones in the mosquito experiment, hence similar effect on offspring could be expected. However, it is not certain whether using inactivated virus for queen exposure affects TGIP, as there are no TGIP studies comparing the efficacy of inactivated versus live viruses (Tetreau et al., 2019). TGIP with killed bacteria has been shown in several systems (Sadd et al., 2005; Yue et al., 2013; Hernández López et al., 2014; Dubuffet et al., 2015; Tate and Graham, 2015; Rosengaus et al., 2017), but with fungal pathogens TGIP was only achieved with live fungi (Fisher and Hajek, 2015; Bordoni et al., 2018). Further, if antiviral TGIP can persist for multiple generations, exposure to DWV in prior generations may have already primed the queens, explaining the lack of further priming effects. Future studies could investigate whether viral derived DNA fragments are present in offspring of honeybee queens challenged with live virus or viral dsRNA, as was seen in the fruit flies by Mondotte et al. (2020).

In our experiment we would have expected to see a lower viral titer and reduced number of deformed wings in the primed group that was infected with the virus, if TGIP had clear beneficial effects for honeybees against viruses. Instead, we saw no reduction in symptoms and complex effects on viral loads. Contrasting results have been found in the nematode host Caenorhabditis elegans, where trans-generational effects were shown to cause viral silencing for many generations (Rechavi et al., 2011). In the moth Plodia interpunctella trans-generational protection against a DNA-virus was seen as lower susceptibility, although viral loads were not measured (Tidbury et al., 2011). The lack of clear TGIP effects in our system could be linked to the low virulence of the particular viral strain used, as typical DWV symptoms were marginal. Still, lack of clear beneficial TGIP effects against a viral pathogen is noteworthy, as the occurrence of and mechanisms TGIP is still being investigated (Tetreau et al., 2019). Theoretically TGIP is predicted when offspring dispersal is low and the pathogen threat is similar between generations (Pigeault et al., 2016). The honeybee offspring live in the same colony as the queen and multiple offspring generation overlap, suggesting that TGIP in this host should be very beneficial.

\section{DATA AVAILABILITY STATEMENT}

The raw data supporting the conclusions of this article will be made available by the authors, without undue reservation.

\section{AUTHOR CONTRIBUTIONS}

DF, ML, and GA contributed to conception, design, and execution of the study. GA provided research materials and facilities. ML wrote the first draft of the manuscript. All authors contributed to revision of the manuscript.

\section{FUNDING}

GA was funded by the Research Council of Norway, award \#262137. The project was funded by Centre of Excellence 
in Biological Interactions, and $\mathrm{ML}$ was funded by Societas Biologica Fennica Vanamo and Helsingin Hyönteistieteellinen Yhdistys.

\section{ACKNOWLEDGMENTS}

Some content of this article has previously appeared in a Master's thesis (Leponiemi, 2018). We thank Dr. Cahit Ozturk for maintaining the honeybees at the Arizona State University Bee Research Facility.

\section{REFERENCES}

Alger, S. A., Burnham, P. A., Boncristiani, H. F., and Brody, A. K. (2019). RNA virus spillover from managed honeybees (Apis mellifera) to wild bumblebees (Bombus spp.). PLoS One 14:e0217822. doi: 10.1371/journal.pone. 0217822

Anderson, D. L., and Gibbs, A. J. (1988). Inapparent Virus Infections and their Interactions in Pupae of the Honey Bee (Apis mellifera Linnaeus) in Australia. J. Gen. Virol. 69, 1617-1625. doi: 10.1099/0022-1317-69-7-1617

Barribeau, S. M., Sadd, B. M., du Plessis, L., Brown, M. J. F., Buechel, S. D., Cappelle, K., et al. (2015). A depauperate immune repertoire precedes evolution of sociality in bees. Genome Biol. 16:83. doi: 10.1186/s13059-0150628-y

Bates, D., Mächler, M., Bolker, B., and Walker, S. (2015). Fitting Linear Mixed-Effects Models Using lme4. J. Stat. Softw. 67:i01. doi: 10.18637/jss. v067.i01

Belzunces, L. P., Kretzschmar, A., Salignon, M., Le Conte, Y., Brunet, J.-L., Suchail, S., et al. (2013). Influence of Pollen Nutrition on Honey Bee Health: Do Pollen Quality and Diversity Matter? PLoS One 8:e72016. doi: 10.1371/journal.pone. 0072016

Bolker, B. M., Brooks, M. E., Clark, C. J., Geange, S. W., Poulsen, J. R., Stevens, M. H. H., et al. (2009). Generalized linear mixed models: a practical guide for ecology and evolution. Trends Ecol. Evol. 24, 127-135. doi: 10.1016/j.tree.2008. 10.008

Boncristiani, H. F., Evans, J. D., Chen, Y., Pettis, J., Murphy, C., Lopez, D. L., et al. (2013). In Vitro Infection of Pupae with Israeli Acute Paralysis Virus Suggests Disturbance of Transcriptional Homeostasis in Honey Bees (Apis mellifera). PLoS One 8:e73429. doi: 10.1371/journal.pone.0073429

Bongaarts, J. (2019). IPBES, 2019. Summary for policymakers of the global assessment report on biodiversity and ecosystem services of the Intergovernmental Science-Policy Platform on Biodiversity and Ecosystem Services. Popul. Dev. Rev. 45, 680-681. doi: 10.1111/padr.12283

Bordoni, A., Dapporto, L., Tatini, I., Celli, M., Bercigli, M., Barrufet, S. R., et al. (2018). Trans-generational immunization in the acrobat ant Crematogaster scutellaris. Biol. Lett. 14:20170761. doi: 10.1098/rsbl.2017.0761

Brutscher, L. M., and Flenniken, M. L. (2015). RNAi and antiviral defense in the honey bee. J. Immunol. Res. 2015:941897. doi: 10.1155/2015/941897

Carrillo-Tripp, J., Dolezal, A. G., Goblirsch, M. J., Miller, W. A., Toth, A. L., and Bonning, B. C. (2016). In vivo and in vitro infection dynamics of honey bee viruses. Sci. Rep. 6:22265. doi: 10.1038/srep22265

de Miranda, J. R., and Genersch, E. (2010). Deformed wing virus. J. Invertebr. Pathol. 103, S48-S61. doi: 10.1016/j.jip.2009.06.012

Desai, S. D., Eu, Y.-J., Whyard, S., and Currie, R. W. (2012). Reduction in deformed wing virus infection in larval and adult honey bees (Apis mellifera L.) by doublestranded RNA ingestion. Insect Mol. Biol. 21, 446-455. doi: 10.1111/j.13652583.2012.01150.x

Donze, G., and Guerin, P. M. (1994). Behavioral atributes and parental care of Varroa mites parasitizing honey bee brood. Behav. Ecol. Sociobiol. 34, 305-319. doi: 10.1007/BF00197001

Dubois, E., Dardouri, M., Schurr, F., Cougoule, N., Sircoulomb, F., and Thiéry, R. (2020). Outcomes of honeybee pupae inoculated with deformed wing virus genotypes A and B. Apidologie 51, 18-34. doi: 10.1007/s13592-019$00701-\mathrm{z}$

\section{SUPPLEMENTARY MATERIAL}

The Supplementary Material for this article can be found online at: https://www.frontiersin.org/articles/10.3389/fevo.2021. 626670/full\#supplementary-material

Supplementary Figure 1 | Pupae on folded filter paper in a Petri dish after injection.

Supplementary Figure 2 | Newly emerged honeybees, when the wing phenotype can be observed for the first time. Example of a honeybee with deformed wings (A) and with properly developed wings, both pairs of wings visible (B).

Dubuffet, A., Zanchi, C., Boutet, G., Moreau, J., Teixeira, M., and Moret, Y. (2015). Trans-generational Immune Priming Protects the Eggs Only against Gram-Positive Bacteria in the Mealworm Beetle. PLoS Pathog. 11:e1005178. doi: 10.1371/journal.ppat.1005178

Erler, S., Popp, M., and Lattorff, H. M. G. (2011). Dynamics of Immune System Gene Expression upon Bacterial Challenge and Wounding in a Social Insect (Bombus terrestris). PLoS One 6:e18126. doi: 10.1371/journal.pone. 0018126

Evans, J. D., Aronstein, K., Chen, Y. P., Hetru, C., Imler, J. L., Jiang, H., et al. (2006) Immune pathways and defence mechanisms in honey bees Apis mellifera. Insect Mol. Biol. 15, 645-656. doi: 10.1111/j.1365-2583.2006.00682.x

Evans, J. D., Schwarz, R. S., Ping Chen, Y., Budge, G., Cornman, R. S., De la Rua, P., et al. (2013). Standard methods for molecular research in Apis mellifera. J. Apic. Res. 52, 1-54. doi: 10.3896/IBRA.1.52.4.11

Farber, D. L., Netea, M. G., Radbruch, A., Rajewsky, K., and Zinkernagel, R. M. (2016). Immunological memory: Lessons from the past and a look to the future. Nat. Rev. Immunol. 16, 124-128. doi: 10.1038/nri.2016.13

Feyereisen, R. (1999). Insect P450 enzymes. Annu. Rev. Entomol. 44, 507-533. doi: 10.1146/annurev.ento.44.1.507

Fievet, J., Tentcheva, D., Gauthier, L., De Miranda, J., Cousserans, F., Colin, M. E., et al. (2006). Localization of deformed wing virus infection in queen and drone Apis mellifera L. Virol. J. 3:16. doi: 10.1186/1743-422X-3-16

Fisher, J. J., and Hajek, A. E. (2015). Maternal exposure of a beetle to pathogens protects offspring against fungal disease. PLoS One 10:e0125197. doi: 10.1371/ journal.pone.0125197

Fitze, P. S., Tschirren, B., and Richner, H. (2004). Life history and fitness consequences of ectoparasites. J. Anim. Ecol. 73, 216-226. doi: 10.1111/j.00218790.2004.00799.x

Forister, M. L., Jahner, J. P., Casner, K. L., Wilson, J. S., and Shapiro, A. M. (2011). The race is not to the swift: Long-term data reveal pervasive declines in California's low-elevation butterfly fauna. Ecology 92, 2222-2235. doi: 10.1890/ 11-0382.1

Fürst, M. A., McMahon, D. P., Osborne, J. L., Paxton, R. J., and Brown, M. J. F. (2014). Disease associations between honeybees and bumblebees as a threat to wild pollinators. Nature 506, 364-366. doi: 10.1038/nature 12977

Grassl, J., Holt, S., Cremen, N., Peso, M., Hahne, D., and Baer, B. (2018). Synergistic effects of pathogen and pesticide exposure on honey bee (Apis mellifera) survival and immunity. J. Invertebr. Pathol. 159, 78-86. doi: 10.1016/j.jip.2018. 10.005

Hallmann, C. A., Sorg, M., Jongejans, E., Siepel, H., Hofland, N., Schwan, H., et al. (2017). More than 75 percent decline over 27 years in total flying insect biomass in protected areas. PLoS One 12:e0185809. doi: 10.1371/journal.pone. 0185809

Hernández López, J., Schuehly, W., Crailsheim, K., and Riessberger-Gallé, U. (2014). Trans-generational immune priming in honeybees. Proc. R. Soc. B 281:20140454. doi: 10.1098/rspb.2014.0454

Hothorn, T., Bretz, F., and Westfall, P. (2008). Simultaneous Inference in Genneral Parametric Models. Biometr. J. 50, 346-363. doi: 10.1002/bimj.200810425

Hunter, W., Ellis, J., Vanengelsdorp, D., Hayes, J., Westervelt, D., Glick, E., et al. (2010). Large-scale field application of RNAi technology reducing Israeli acute paralysis virus disease in honey bees (Apis mellifera, hymenoptera: Apidae). PLoS Pathog. 6:1001160. doi: 10.1371/journal.ppat.1001160 
Kammenga, J. E., Van Koert, P. H. G., Koeman, J. H., and Bakker, J. (1997). Fitness consequences of toxic stress evaluated within the context of phenotypic plasticity. Ecol. Appl. 7, 726-734. doi: 10.1890/1051-07611997007[0726: FCOTSE] 2.0.CO;2

Kassambara, A., and Kosinski, M. (2017). survminer: Drawing Survival Curves using "ggplot2". Vienna: R Core Team.

Klein, A.-M., Vaissiere, B. E., Cane, J. H., Steffan-Dewenter, I., Cunningham, S. A., Kremen, C., et al. (2007). Importance of pollinators in changing landscapes for world crops. Proc. R. Soc. B. 274, 303-313. doi: 10.1098/rspb.2006.3721

Klink, R., van, Bowler, D. E., Gongalsky, K. B., Swengel, A. B., Gentile, A., et al. (2020). Meta-analysis reveals declines in terrestrial but increases in freshwater insect abundances. Science 368, 417-420. doi: 10.1126/SCIENCE.AAX9931

Lemaitre, B., and Hoffmann, J. (2007). The Host Defense of Drosophila melanogaster. Annu. Rev. Immunol. 25, 697-743. doi: 10.1146/annurev. immunol.25.022106.141615

Leponiemi, M. (2018). Vaccination of honey bees against Deformed Wing Virus. Ph. D. thesis, Helsinki: University of Helsinki.

Livak, K. J., and Schmittgen, T. D. (2001). Analysis of relative gene expression data using real-time quantitative PCR and the 2- $\Delta \Delta$ CT method. Methods 25, 402-408. doi: 10.1006/meth.2001.1262

Martin, S. J., and Brettell, L. E. (2019). Deformed Wing Virus in Honeybees and Other Insects. Annu. Rev. Virol. 6, 49-69. doi: 10.1146/annurev-virology092818-015700

Mazzei, M., Carrozza, M. L., Luisi, E., Forzan, M., Giusti, M., Sagona, S., et al. (2014). Infectivity of DWV associated to flower pollen: Experimental evidence of a horizontal transmission route. PLoS One 9:e113448. doi: 10.1371/journal. pone. 0113448

McMahon, D. P., Natsopoulou, M. E., Doublet, V., Fürst, M., Weging, S., Brown, M. J. F., et al. (2016). Elevated virulence of an emerging viral genotype as a driver of honeybee loss. Proc. R. Soc. B 283:20160811. doi: 10.1098/rspb.2016. 0811

Milutinović, B., and Kurtz, J. (2016). Immune memory in invertebrates. Semin. Immunol. 28, 328-342. doi: 10.1016/j.smim.2016.05.004

Möckel, N., Gisder, S., and Genersch, E. (2011). Horizontal transmission of deformed wing virus: Pathological consequences in adult bees (Apis mellifera) depend on the transmission route. J. Gen. Virol. 92, 370-377. doi: 10.1099/vir.0. 025940-0

Mondotte, J. A., Gausson, V., Frangeul, L., Suzuki, Y., Vazeille, M., Mongelli, V., et al. (2020). Evidence For Long-Lasting Transgenerational Antiviral Immunity in Insects. Cell Rep. 33:108506. doi: 10.1016/j.celrep.2020. 108506

Moreno-García, M., Condé, R., Bello-Bedoy, R., and Lanz-Mendoza, H. (2014). The damage threshold hypothesis and the immune strategies of insects. Infect. Genet. Evol. 24, 25-33. doi: 10.1016/j.meegid.2014.02.010

Moret, Y., and Schmid-Hempel, P. (2000). Survival for immunity: The price of immune system activation for bumblebee workers. Science 290, 1166-1168. doi: $10.1126 /$ science.290.5494.1166

Nazzi, F., and Le Conte, Y. (2016). Ecology of Varroa destructor, the Major Ectoparasite of the Western Honey Bee, Apis mellifera. Annu. Rev. Entomol. 61, 417-432. doi: 10.1146/annurev-ento-010715-023731

Nazzi, F., Brown, S. P., Annoscia, D., Del Piccolo, F., Di Prisco, G., Varricchio, P., et al. (2012). Synergistic parasite-pathogen interactions mediated by host immunity can drive the collapse of honeybee colonies. PLoS Pathog. 8:e1002735. doi: 10.1371/journal.ppat.1002735

Pigeault, R., Garnier, R., Rivero, A., and Gandon, S. (2016). Evolution of transgenerational immunity in invertebrates. Proc. R. Soc. B 283:20161136. doi: 10.1098/rspb.2016.1136

Pinheiro, J., Bates, D., DebRoy, S., Sarkar, D., and Team, R. C. (2021). Linear and Nonlinear Mixed Effects Models. Vienna: R Core Team.

R Core Team (2017). R: A language and environment for statistical computing. Vienna: R Core Team.

Ramsey, S. D., Ochoa, R., Bauchan, G., Gulbronson, C., Mowery, J. D., Cohen, A., et al. (2019). Varroa destructor feeds primarily on honey bee fat body tissue and not hemolymph. Proc. Natl. Acad. Sci. U S A. 116, 1792-1801. doi: $10.1073 /$ pnas. 1818371116

Rechavi, O., Minevich, G., and Hobert, O. (2011). Transgenerational inheritance of an acquired small RNA-based antiviral response in C. elegans. Cell 147, 1248-1256. doi: 10.1016/j.cell.2011.10.042
Remnant, E. J., Mather, N., Gillard, T. L., Yagound, B., and Beekman, M. (2019). Direct transmission by injection affects competition among RNA viruses in honeybees. Proc. R. Soc. B 286:20182452. doi: 10.1098/rspb.2018.2452

Rosengaus, R. B., Hays, N., Biro, C., Kemos, J., Zaman, M., Murray, J., et al. (2017). Pathogen-induced maternal effects result in enhanced immune responsiveness across generations. Ecol. Evol. 7, 2925-2935. doi: 10.1002/ece3.2887

Rosenkranz, P., Aumeier, P., and Ziegelmann, B. (2009). Biology and control of Varroa destructor. J. Invertebr. Pathol. 103, S96-S119. doi: 10.1016/j.jip.2009.07. 016

Roth, O., Sadd, B. M., Schmid-Hempel, P., and Kurtz, J. (2009). Strain-specific priming of resistance in the red flour beetle, Tribolium castaneum. Proc. R. Soc. B 276, 145-151. doi: 10.1098/rspb.2008.1157

Ryabov, E. V., Childers, A. K., Lopez, D., Grubbs, K., Posada-Florez, F., Weaver, D., et al. (2019). Dynamic evolution in the key honey bee pathogen deformed wing virus: Novel insights into virulence and competition using reverse genetics. PLoS Biol. 17:e3000502. doi: 10.1371/journal.pbio.3000502

Sadd, B. M., and Schmid-Hempel, P. (2006). Insect Immunity Shows Specificity in Protection upon Secondary Pathogen Exposure. Curr. Biol. 16, 1206-1210. doi: 10.1016/j.cub.2006.04.047

Sadd, B. M., and Schmid-Hempel, P. (2009). A distinct infection cost associated with trans-generational priming of antibacterial immunity in bumble-bees. Biol. Lett. 5, 798-801. doi: 10.1098/rsbl.2009.0458

Sadd, B. M., Kleinlogel, Y., Schmid-Hempel, R., and Schmid-Hempel, P. (2005). Trans-generational immune priming in a social insect. Biol. Lett. 1, 386-388. doi: $10.1098 / \mathrm{rsbl} .2005 .0369$

Salmela, H., Amdam, G. V., and Freitak, D. (2015). Transfer of Immunity from Mother to Offspring Is Mediated via Egg-Yolk Protein Vitellogenin. PLoS Pathog. 11:e1005015. doi: 10.1371/journal.ppat.1005015

Sánchez-Bayo, F., and Wyckhuys, K. A. G. (2019). Worldwide decline of the entomofauna: A review of its drivers. Biol. Conserv. 232, 8-27. doi: 10.1016/j. biocon.2019.01.020

Schulz, N. K. E., Sell, M. P., Ferro, K., Kleinhölting, N., and Kurtz, J. (2019). Transgenerational developmental effects of immune priming in the red flour beetle Tribolium castaneum. Front. Physiol. 10:98. doi: 10.3389/fphys.2019. 00098

Sih, A., Bell, A. M., and Kerby, J. L. (2004). Two stressors are far deadlier than one. Trends Ecol. Evol. 19, 274-276. doi: 10.1016/j.tree.2004.02.010

Siva-Jothy, M. T., Moret, Y., and Rolff, J. (2005). Insect Immunity: An Evolutionary Ecology Perspective. Adv. Insect Phys. 32, 1-48. doi: 10.1016/S0065-2806(05) 32001-7

Skerratt, L. F., Berger, L., Speare, R., Cashins, S., McDonald, K. R., Phillott, A. D., et al. (2007). Spread of chytridiomycosis has caused the rapid global decline and extinction of frogs. Ecohealth 4, 125-134. doi: 10.1007/s10393-007-0093-5

Smith, K. M., Loh, E. H., Rostal, M. K., Zambrana-Torrelio, C. M., Mendiola, L., and Daszak, P. (2013). Pathogens, pests, and economics: Drivers of honey bee colony declines and losses. Ecohealth 10, 434-445. doi: 10.1007/s10393-0130870-2

Tate, A. T., and Graham, A. L. (2015). Trans-generational priming of resistance in wild flour beetles reflects the primed phenotypes of laboratory populations and is inhibited by co-infection with a common parasite. Funct. Ecol. 29, 1059-1069. doi: 10.1111/1365-2435.12411

Tehel, A., Vu, Q., Bigot, D., Gogol-Döring, A., Koch, P., Jenkins, C., et al. (2019). The Two Prevalent Genotypes of an Emerging Infectious Disease, Deformed Wing Virus, Cause Equally Low Pupal Mortality and Equally High Wing Deformities in Host Honey Bees. Viruses 11:114. doi: 10.3390/v11020114

Tetreau, G., Dhinaut, J., Gourbal, B., and Moret, Y. (2019). Trans-generational immune priming in invertebrates: Current knowledge and future prospects. Front. Immunol. 10:1938. doi: 10.3389/fimmu.2019.01938

Therneau, T. M. (2015). A Package for Survival Analysis in R. version 2.38. Vienna: R Core Team.

Tidbury, H. J., Pedersen, A. B., and Boots, M. (2011). Within and transgenerational immune priming in an insect to a DNA virus. Proc. R. Soc. B 278, 871-876. doi: $10.1098 / \mathrm{rspb} .2010 .1517$

Trauer, U., and Hilker, M. (2013). Parental Legacy in Insects: Variation of Transgenerational Immune Priming during Offspring Development. PLoS One 8:e63392. doi: 10.1371/journal.pone.0063392

Williams, G. R., Alaux, C., Costa, C., Csáki, T., Doublet, V., Eisenhardt, D., et al. (2013). Standard methods for maintaining adult Apis mellifera in cages 
under in vitro laboratory conditions. J. Apic. Res. 52, 1-36. doi: 10.3896/IBRA. 1.52.1.04

Yue, C., and Genersch, E. (2005). RT-PCR analysis of Deformed wing virus in honeybees (Apis mellifera) and mites (Varroa destructor). J. Gen. Virol. 86, 3419-3424. doi: 10.1099/vir.0.81401-0

Yue, F., Zhou, Z., Wang, L., Ma, Z., Wang, J., Wang, M., et al. (2013). Maternal transfer of immunity in scallop Chlamys farreri and its trans-generational immune protection to offspring against bacterial challenge. Dev. Comp. Immunol. 41, 569-577. doi: 10.1016/j.dci.2013. 07.001

Zanchi, C., Troussard, J. P., Martinaud, G., Moreau, J., and Moret, Y. (2011). Differential expression and costs between maternally and paternally derived immune priming for offspring in an insect.
J. Anim. Ecol. 80, 1174-1183. doi: 10.1111/j.1365-2656.2011.01 872.x

Conflict of Interest: The authors declare that the research was conducted in the absence of any commercial or financial relationships that could be construed as a potential conflict of interest.

Copyright (c) 2021 Leponiemi, Amdam and Freitak. This is an open-access article distributed under the terms of the Creative Commons Attribution License (CC BY). The use, distribution or reproduction in other forums is permitted, provided the original author(s) and the copyright owner(s) are credited and that the original publication in this journal is cited, in accordance with accepted academic practice. No use, distribution or reproduction is permitted which does not comply with these terms. 